\title{
Kunnskapsbasert praksis for norske leger? 迷
}

\author{
En fersk rapport fra Kunnskapssenteret belyser hvorfor og hvordan kunnskapsbasert praksis bør innføres \\ i spesialisthelsetjenesten. Vi håper Legeforeningen tydelig vil bidra til at norske leger kan og vil bruke \\ forskningsbasert kunnskap på en balansert måte i klinisk praksis.
}

\begin{abstract}
«Kunnskapsbasert praksis» er å integrere den beste tilgjengelige forskningskunnskapen med klinisk ekspertise og pasientens preferanser (1). Begrepet kommer fra det engelske «evidence-based clinical practice». Forståelsen og utbredelsen av kunnskapsbasert praksis er imidlertid lav (2). Få er klar over at mesteparten av forskningen i medisinske databaser som PubMed er upålitelig på grunn av feilkilder (3). Kunnskapsbasert praksis som arbeidsform fordrer at leger har grunnleggende ferdigheter i kunnskapshåndtering og tilgang til brukervennlige verktøy, dessuten organisatorisk tilrettelegging.
\end{abstract}

\section{Foretaksprosjektet}

Foretaksprosjektet ble gjennomført av Nasjonalt kunnskapssenter for helsetjenesten i samarbeid med Sykehuset Innlandet under ledelse av artikkelforfatterne. Bestillingen kom fra Helse Øst, som i 2005 ba om støtte til å innføre kunnskapsbasert praksis i helseforetakene. I vår rapport (4) oppsummeres fire års systematisk arbeid med å innføre kunnskapsbasert praksis i Sykehuset Innlandet. Vi foreslår der et rammeverk med fire dimensjoner: kompetanse, organisering, teknologisk infrastruktur og verktøy for kunnskapsstøtte.

\section{Kompetanse}

Det er behov for grunnleggende kompetanseheving blant klinikere og beslutningstakere. Det foreligger stadig bedre undervisningstilbud, bl.a. ved et økende antall kurs (f.eks. nettkurset www.kunnskapsbasertpraksis.no) og utdanningsprogrammer både lokalt og nasjonalt. Gode undervisningstilbud i grunn- og etterutdanning og kompetansemiljøer som kan gi støtte og veiledning lokalt og regionalt bør etableres.

\section{Organisering}

Innføring av kunnskapsbasert praksis som arbeidsform krever kultur- og organisasjonsendring og systematisk arbeid over år. Et organisatorisk tiltak utprøvd i Sykehuset Innlandet er rekruttering av en tverrfaglig gruppe dedikerte fagfolk med støtte $i$ ledelsen og tid til å gjennomføre arbeidet. Snarere enn å etablere frittstående prosjekter har vi i foretaket vevd kunnskapsbasert praksis inn i pågående prosesser knyttet til fagutvikling og kvalitetsarbeid.

\section{Teknologisk infrastruktur}

Tilstrekkelig infrastruktur er en forutsetning for kunnskapsbasert praksis. Klinikere i norske sykehus trenger fullverdig tilgang til PC, Internett og mobile enheter, uten dagens begrensninger i funksjonalitet. Tungvint pålogging, mangelfull tilgang til fullverdig e-læring og vanskelig tilgjengelige lokale prosedyrer må utbedres. Smarttelefonen gir rask tilgang til stadig bedre webbaserte kunnskapsverktøy.

\section{Kunnskapskilder}

og verktøy for kunnskapsstøtte

Et økende antall verktøy gir helsepersonell tilgang til gyldig forskningskunnskap. Rapporten gjengir erfaringer fra utprøvning av ulike kunnskapsverktøy i foretaket. Helsebiblioteket ( $w w w$.helsebiblioteket.no) er en portal for helsepersonell som gir fri tilgang til kunnskapsbaserte retningslinjer og oppslagsverk (som UpToDate), tidsskrifter og databaser. Kunnskapspyramiden (6 Smodellen) hjelper klinikere til å finne gyldig og anvendelig kunnskap om diagnostikk, prognose og behandling (5). «Kunnskapsraffineriet» McMaster PLUS, nå tilgjengelig på Helsebiblioteket, identifiserer de få nye studiene som både er gyldige og relevante og serverer disse via e-postvarsel og gjennom en egen søkemotor. Tjenesten muliggjør effektive kunnskapssøk i alle nivåer av Kunnskapspyramiden, utløst av ett eller to søkeord.

Å utvikle råd og anbefalinger om diagnostikk og behandling til fagfolk krever kompetanse i både fag og forskningsmetodikk. Erfaringer fra foretaksprosjektet med å utvikle, formidle og oppdatere fagprosedyrer og kliniske retningslinjer viser et behov for systematisk forbedringsarbeid. Verktøy som GRADE og AGREE bidrar til at anbefalinger for fagfolk er balanserte, ved å integrere forskningsbasert kunnskap, klinisk ekspertise og pasientpreferanser i lokal og nasjonal kontekst $(6,7)$.

\section{Hvem har ansvaret for kunnskapsbasert praksis?}

Arbeidet med å implementere kunnskapsbasert praksis i norsk spesialisthelsetjeneste er fortsatt i en tidlig fase. Kultur og arbeidsmåte må endres, kompetansen blant klinikere og beslutningstakere styrkes og tilgangen til verktøy for kunnskapsstøtte i helseforetakene økes. Målrettet og omfattende nasjonal og regional innsats er nødvendig dersom balansert bruk av forskningsbasert kunnskap skal bli en naturlig og integrert del av hverdagen. Det er på høy tid at norske leger får grunnleggende ferdigheter i kunnskapsbasert praksis.
Vi håper at Legeforeningen, med sin vektlegging på fagutvikling og kvalitet, vil bidra sterkt til å innføre kunnskapsbasert praksis i norsk helsetjeneste gjennom systematisk etterutdanning og som en naturlig del av fagutvikling, pasientsikkerhetsarbeid og kvalitetsforbedring.

\section{Per Olav Vandvik}

per.vandvik@gmail.com

Nasjonalt kunnskapssenter for helsetjenesten og

Medisinsk avdeling, Sykehuset Innlandet Gjøvik

\section{Øystein Eiring}

Avdeling for kunnskapsstøtte

Sykehuset Innlandet

Per Olav Vandvik (f. 1968) er dr.med. og førsteamanuensis ved Avdeling for allmennmedisin, Institutt for helse og samfunn, Universitetet

i Oslo. Han er forsker ved Kunnskapssenteret og konstituert overlege ved Medisinsk avdeling. Sykehuset Innlandet, Gjøvik.

Ingen oppgitte interessekonflikter.

Øystein Eiring (f. 1966) er spesialist i psykiatri, avdelingssjef for Avdeling for kunnskapsstøtte ved Sykehuset Innlandet og redaktør for Emnebibliotek psykisk helse ved Helsebiblioteket. Han har arbeidet som allmennlege, medisinsk journalist og overlege i psykiatri.

Ingen oppgitte interessekonflikter.

\section{Litteratur}

1. Sackett DL, Rosenberg WM, Gray JA et al. Evidence based medicine: what it is and what it isn't. BMJ 1996; 312: 71-2.

2. Guyatt G, Cook D, Haynes B. Evidence based medicine has come a long way. BMJ 2004; 329 . $990-1$

3. loannidis JP. Why most published research findings are false. PLoS Med 2005; 2: e124.

4. Vandvik PO, Eiring $\varnothing$. Foretaksprosjektet: mot kunnskapsbasert praksis i spesialisthelsetjenesten. Oslo: Nasjonalt kunnskapssenter for helsetjenesten, 2011

5. DiCenso A, Bayley L, Haynes RB. ACP Journal Club. Editorial: accessing preappraised evidence: fine-tuning the $5 \mathrm{~S}$ model into a $6 \mathrm{~S}$ model. Ann Intern Med 2009; 151: JC3-2, JC3-3.

6. Guyatt GH, Oxman AD, Vist GE et al. GRADE: an emerging consensus on rating quality of evidence and strength of recommendations. BMJ 2008; 336 : $924-6$.

7. Brouwers MC, Kho ME, Browman GP et al. AGREE II: advancing guideline development, reporting and evaluation in health care. J Clin Epidemiol 2010; 63: $1308-11$

Mottatt 8.7. 2011, første revisjon innsendt 25.7. 2011, godkjent 4.8. 2011. Medisinsk redaktør Siri Lunde.

Engelsk oversettelse av hele artikkelen

på www.tidsskriftet.no 